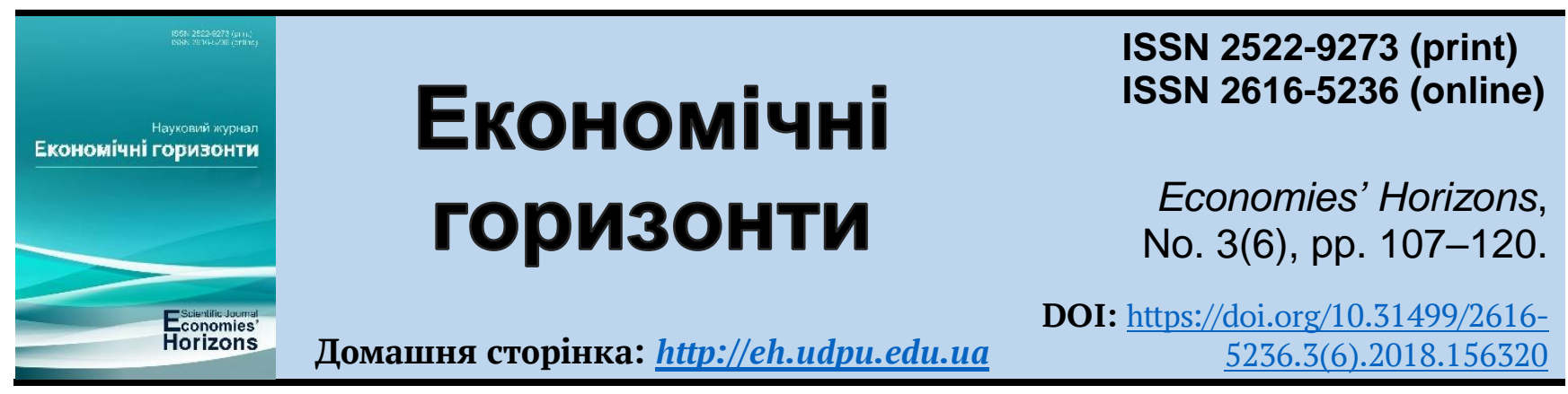

УДК 338.48

Формування конкурентоспроможності готельних послуг регіону

Стаття надійшла: 12.09 .2018

I. М. Поворознюк ${ }^{1}$, к. е. н., доцент

Л. А. Слатвінська ${ }^{2}$ к. е. н.

Т. М. Бербец ${ }^{3}$, к. пед. н.

Стаття прийнята: 26.09.2018

Поворознюк І. М., Слатвінська Л. А., Бербец Т. М. Формування конкурентоспроможності готельних послуг регіону. Економічні горизонти. 2018. № 3(6). C. 107-120. DOI: 10.31499/2616-5236.3(6).2018.156320.

Анотація. Метою статті є дослідження теоретико-методичних засад формування конкурентоспроможного ринку готельних послуг регіону і обгрунтування напрямів підвищення його ефективності та функціонування в ринкових умовах господарювання. Досліджується ринок готельних послуг регіону та оцінка факторів впливу на його формування. Методологія дослідження базується на фундаментальних положень розвитку регіональної економіки, економічної теорії, економіки сфери послуг, менеджменту, маркетингу готельного господарства, теорії конкурентних переваг, публікації вітчизняних та зарубіжних вчених з питань управління готельним господарством, підвищення його конкурентоспроможності. Обмеженнями у проведеному дослідженні $є$ неповнота статистичних даних, що підлягають оприлюдненню Державною службою статистики України, головним управлінням статистики області, міста, району. Результати. Доведено, що процес формування конкурентоспроможності готельних послуг $є$ трудомістким і вимагає від готелів постійної роботи по удосконаленню свої діяльності тому, що більшість ресурсів, які створюють конкурентні переваги є легко доступні для конкурентів. Проаналізовано ринок готельних послуг регіону, а саме конкурентні переваги найбільших готелів, де визначено завдяки яким факторам готель «Умань» займає високе місце в рейтингу. Формування його конкурентоспроможності забезпечується завдяки факторам: репутацією готелю, автоматизацією процесом управління, якістю послуг та контролем за нею, середньорічним завантаженням, середньорічною реалізацією номерного фонду. Але адміністрації готелю необхідно звернути увагу на проблемні місця, зокрема: кваліфікацію менеджерів, плинність кадрів, маркетингову політику. Доведено, що про формуванні конкурентоспроможної готельної послуги підприємство повинне мати високу репутацію, лояльний та професійний персонал, ефективний маркетинг та використовувати ефективні системи управління. При формуванні певних рекомендацій (пропозицій) щодо управління конкурентоспроможності готельних послуг для всіх підприємств бути стандартними не можуть.

\footnotetext{
${ }^{1}$ Уманський державний педагогічний університет імені Павла Тичини; завідувач кафедри технологій та організації туризму i готельно-ресторанної справи; ідентифікатор ORCID: https://orcid.org/0000-0002-2575-5114; e-mail: inna-173@ukr.net.

${ }^{2}$ Уманський державний педагогічний університет імені Павла Тичини; доцент кафедри технологій та організації туризму i готельно-ресторанної справи; ідентифікатор ORCID: https://orcid.org/0000-0002-6747-2374; e-mail: slatvinska8888@ukr.net.

${ }^{3}$ Уманський державний педагогічний університет імені Павла Тичини; доцент кафедри технологій та організації туризму i готельно-ресторанної справи; ідентифікатор ORCID: https://orcid.org/0000-0002-9334-7112; e-mail: berbec08@ukr.net.
} 
Вони повинні бути сформовані для кожного підприємства свої, які оптимально будуть працювати 3 урахуванням усіх специфічних характеристик та особливостей даного підприємства. Обгрунтовано, що конкурентоспроможність готельної послуги можна виміряти за допомогою системи показників: економічних, маркетингових та якісних. Але слід пам'ятати, що оцінка конкурентоспроможності готельних послуг носить умовний характер, так як оцінювання конкурентоспроможної готельної послуги є суб’єктивним чинником і залежить від думок, вимог, потреб окремих груп споживачів. Практичне значення. Обгрунтовано напрями підвищення конкурентоспроможності готельних послуг регіону. Перспективи подальших досліджень полягають у дослідженнях кількісного обгрунтовування систем груп показників, за допомогою яких можна виміряти конкурентоспроможність готельної послуги регіону.

Ключові слова: готельна послуга, конкурентоспроможність, регіон, конкурентні переваги, формування конкурентних переваг.

JEL Classification: D 41, L 83

\title{
Formation of competitiveness of the region hotel services
}

\author{
Inna M. Povorozniuk ${ }^{1}$, Cand. Ec. Sc., Associate Professor \\ Lesia A. Slatvinska ${ }^{2}$, Cand. Ec. Sc. \\ Tetiana M. Berbets ${ }^{3}$, Cand. Ped. Sc.
}

Received: 12 September 2018 Accepted: 26 September 2018
Povorozniuk, I. M., Slatvinska, L. A. and Berbets, T. M. (2018), "Formation of competitiveness of the region hotel services", Economies' Horizons, No. 3(6), pp. 107120, doi: https://doi.org/10.31499/2616-5236.3(6).2018.156320.

\begin{abstract}
The purpose of the research is to analyse theoretical and methodological principles of forming a competitive market for hotel services in the region and to substantiate directions for improving its efficiency and functioning in market conditions of management. The market of hotel services of the region is studied and an estimation of factors of influence on its formation. Methodology. The methodology of the research is based on the fundamental provisions of the development of the regional economy, economic theory, the economy of the service sector, management, marketing of the hotel industry, the theory of competitive advantages, the publication of domestic and foreign scientists on the management of hospitality, increase its competitiveness. The restrictions in the conducted research are incomplete statistical data, which are subject to disclosure by the State Statistics Service of Ukraine, the main department of statistics of the region, city, district. Results. It is proved that the process of forming the competitiveness of hotel services is time-consuming and requires the hotels to work continuously to improve their activities because most of the resources that create competitive advantages are easily available to competitors. The market of hotel services of the region is analyzed, namely, the competitive advantages of the largest hotels, which is determined by what factors Uman Hotel occupies a high place in the rating. Formation of its competitiveness is ensured by the factors: hotel reputation, automation of the management process, quality of services and control over it, average annual load, the average annual implementation of the number fund. But the hotel administration needs to pay attention to the problem areas, in particular: qualification of managers, turnover of personnel, marketing policy. It is proved that the company should have a high reputation, loyal and professional staff, efficient marketing and effective management systems to form a competitive hotel service. When forming certain recommendations (pro-
\end{abstract}

\footnotetext{
${ }^{1}$ Pavlo Tychyna Uman State Pedagogical University; Head of the Department of Technology and Organization of Tourism, Hotel \& Restaurant Business; ORCID ID: https://orcid.org/0000-0002-2575-5114; e-mail: inna-173@ukr.net.

${ }^{2}$ Pavlo Tychyna Uman State Pedagogical University; Associate Professor at the Department of Technology and Organization of Tourism, Hotel \& Restaurant Business; ORCID ID: https://orcid.org/0000-0002-6747-2374; e-mail: slatvinska8888@ukr.net.

${ }^{3}$ Pavlo Tychyna Uman State Pedagogical University; Associate Professor at the Department of Technology and Organization of Tourism, Hotel \& Restaurant Business; ORCID ID: https://orcid.org/0000-0002-9334-7112; e-mail:berbec08@ukr.net.
} 
posals) on the management of the competitiveness of hotel services for all enterprises can not be standard. They must be formed for each enterprise, which will work optimally, taking into account all the specific characteristics and characteristics of the enterprise. It is substantiated that the competitiveness of a hotel service can be measured using a system of indicators: economic, marketing and quality. But it should be remembered that the assessment of the competitiveness of hotel services is conditional, as the evaluation of a competitive hotel service is a subjective factor and depends on the thoughts, requirements, needs of individual groups of consumers. Practical meaning. The directions of increase of competitiveness of hotel services of the region are substantiated. Prospects for further research are the research of quantitative substantiation of the systems of groups of indicators, by which one can measure the competitiveness of the hotel services of the region.

Keywords: hotel service, competitiveness, region, competitive advantages, formation of competitive advantages.

\section{Bcmyn.}

Актуальним завданням української економіки в іiі стратегічній перспективі $\epsilon$ розвиток українського ринку готельних послуг та підвищення рівня конкурентоспроможності. Виникнення та розвиток суспільства $з$ давніх часів завжди супроводжувався формуванням явища конкуренція. Саме розуміння поняття слова «конкуренція» в перекладі від латинського означає - змагатися, а отже всі ми розуміємо, що якщо підприємство хоче ефективно функціонувати та укріплювати свої позиції на певному сегменті ринку то воно повинне аналізувати та реагувати на зміни які його оточують.

На думку Ф. Котлера (Kotler, 2006), конкурентоспроможність визначає компетентність, що дозволяє витримувати конкуренцію порівняно 3 аналогічними суб'єктами на цьому ринку.

Надання конкурентоспроможних готельних послуг виступає найважливішим фактором забезпечення виживання готелю в нестабільних умовах господарювання та його подальшим ефективним розвитком.

Регіональні ринки готельних послуг мають найвищий рівень конкуренції, що потребує постійного пошуку стійких конкурентних переваг в подальшій своїй діяльності.

\section{2. Аналіз останніх досліджень і пуб- лікацій з проблеми. \\ Дослідженню проблем формування конкурентоспроможності готельних послуг в тому числі на регіональному рівні прис- вячено численні праці вітчизняних вчених,}

зокрема Л. Батченко та Т. Стариченко (Batchenko and Starychenko, 2018), С. Галасюк (Halasiuk, 2014), Л. Завідної (Zavidna, 2018), В. Охоти (Okhota, 2017), I. Поворознюк (Povorozniuk, 2017), П. Подлепіної (Podlepina, 2016), О. Полтавської (Poltavska, 2016), А. Ткаченко та Ю. Лелі (Tkachenko and Leli, 2016), О. Шикіна (Shykina, 2016).

Даній проблематиці присвячено праці західних науковців: Е. Фредж, І. Мейтуті (Fraj and Matutef, 2015), Л. Лі та М. Пендж (Li and Peng, 2017), Дж. Моліна-Азорін та Дж. Tapi (Molina-Azorín and Tarí, 2015), I. Мохамід та Б. Кюілет (Mohammed and Guillet, 2015), Г. Зервас та Д. Просерпіо (Zervas and Proserpio, 2017) та інших. Незважаючи на вагомий доробок вітчизняних та зарубіжних вчених 3 проблем формування конкурентоспроможності готельних послуг, регіональні ринки потребують постійного пошуку стійких конкурентних переваг.

\section{3. Методи дослідження.}

У процесі дослідження використано: діалектичний метод і загальнонаукові методи пізнання: метод теоретичного узагальнення, системного аналізу та синтезу (для дослідження сутності конкурентоспроможності готельних послуг); порівняльного аналізу (для оцінки розвитку готельного господарства та визначення конкурентних переваг); структурний метод, статистичні та математичні методи (для аналізу тенденцій розвитку готельних послуг регіону). 


\section{4. Формулювання цілей дослі-} дження.

Метою статті $€$ дослідження теоретико-методичних засад формування конкурентоспроможного ринку готельних послуг регіону i обгрунтування напрямів підвищення його ефективності та функціонування в ринкових умовах господарювання.

5. Виклад основних результатів та їх обгрунтування.

Індустрія гостинності $є$ візитною карточкою України в тому числі Уманщини і $є$ показником іiі соціально-культурного та економічного розвитку. Ії розвиток $\epsilon$ важливим елементом інтеграції українського туристичного ринку в європейський бізнес і культурне середовище. Динаміка розвитку готельного господарства Уманщини має не стійку тенденцію. Це пов'язано з соціально-економічною та політичною ситуацією в країні, сезонністю наданих послуг, невідповідністю цінової політики, якості надання послуг та високим рівнем конкурентоспроможності.

Щоб детально проаналізувати динаміку розвитку готельного господарства Уманщини перейдемо до його аналізу (табл. 1 і табл. 2).

Таблиця 1. Динаміка розвитку засобів розміщування Уманщини за 2016-2018 pр.

\begin{tabular}{|c|c|c|c|}
\hline \multirow{2}{*}{ Тип закладу готельного господарства } & \multicolumn{3}{|c|}{ Кількість закладів готельного господарства за роками: } \\
\hline & 2016 & 2017 & 2018 \\
\hline \multicolumn{4}{|c|}{ Готелі } \\
\hline «Умань» & 1 & 1 & 1 \\
\hline «Azuhat Ohalei Shalom» & - & 1 & 1 \\
\hline «One» & - & 1 & 1 \\
\hline «Beit Chazin» & - & 1 & 1 \\
\hline «Hoshen» & - & 1 & 1 \\
\hline «Mini Hotel» & - & 1 & 1 \\
\hline «Умань Plaza» & 1 & 1 & 1 \\
\hline «Софієвський» & 1 & 1 & 1 \\
\hline «Корнет» & 1 & 1 & 1 \\
\hline «Pozitiv» & - & 1 & 1 \\
\hline «Готель УНУС» & 1 & 1 & 1 \\
\hline Всього & 5 & 11 & 11 \\
\hline \multicolumn{4}{|c|}{ Апартаменти та гостьові будинки } \\
\hline «OLMA5 -1» & - & 1 & 1 \\
\hline «Heichal Hagwanim» & - & 3 & 3 \\
\hline «mini cottage Ludmila» & - & 1 & 1 \\
\hline «Апартаменти» & 1 & 1 & 1 \\
\hline «Golden Park Apartaments» & - & 1 & 1 \\
\hline Всього & 1 & 7 & 7 \\
\hline \multicolumn{4}{|c|}{ Гуртожитки } \\
\hline Гуртожиток УПЛ 9 & 1 & 1 & 1 \\
\hline Гуртожиток УАТК & 1 & 1 & 1 \\
\hline Гуртожиток «Уманьферммаш» & 1 & 1 & 1 \\
\hline Гуртожиток УНУС 1 & 1 & 1 & 1 \\
\hline Гуртожиток УНУС 2 & 1 & 1 & 1 \\
\hline Гуртожиток УНУС 3 & 1 & 1 & 1 \\
\hline Гуртожиток УНУС 4 & 1 & 1 & 1 \\
\hline Гуртожиток УНУС 5 & 1 & 1 & 1 \\
\hline Гуртожиток УДПУ 1 & 1 & 1 & 1 \\
\hline Гуртожиток УДПУ 2 & 1 & 1 & 1 \\
\hline Всього & 10 & 10 & 10 \\
\hline \multicolumn{4}{|c|}{ Хостели } \\
\hline «Фортеця» & 1 & 1 & 1 \\
\hline «Hindik Hostel» & - & 1 & 1 \\
\hline Всього & 1 & 2 & 2 \\
\hline Всього по Уманщині & 17 & 30 & 30 \\
\hline
\end{tabular}

Джерело: сформовано за даними Сайта міста Умань (Sait mista Uman, 2018), Трипадвизор Умань (Trypadvyzor Uman, 2018), Туристический гипермаркет (Turystycheskyi hypermarket, 2018), Украина Центральная. Умань (Ukrayna Tsentralnaia. Uman, 2018), Умань туристична (Uman turystychna, 2018). 
Аналізуючи дані табл. 1 ми бачимо, що кількість засобів розміщування становить 30 одиниць. За період з 2016 року кількість засобів готельного господарства збільшилася на 13 одиниць, це вказує на позитивну динаміку розвитку. Але слід зауважити, що в структурі номерного фонду переважають готелі які не мають зіркової категорії. На жаль власники готелів не зацікавлені в проходженні процедури присвоєння їм відповідного класу категорії (зірковості).
Висока завантаженість засобів розміщування в регіоні відбувається весною та восени, що пояснюється активним діловим життям, приїзду туристів з різною метою в тому числі паломників.

На ринку індустрії гостинності Уманщини функціонує також 12 одиниць готельно-ресторанних, спортивно-оздоровчих, розважальних комплексів. За 20162018 роки їх кількість збільшилася на 2 одиниці.

\section{Таблиця 2. Динаміка розвитку спортивно-оздоровчих, розважальних та готельно- ресторанних комплексів Уманщини за 2016-2018 pp.}

\begin{tabular}{|c|c|c|c|}
\hline \multirow{2}{*}{ Тип та назва закладу } & \multicolumn{3}{|c|}{ Кількість закладів індустрії гостинності } \\
\hline & 2016 рік & 2017 piк & 2018piк \\
\hline «Спортивно-оздоровчий комплекс» & 1 & 1 & 1 \\
\hline Готельно-ресторанний комплекс «Слобода. Хуторок» & 1 & 1 & 1 \\
\hline Готельно-ресторанний комплекс «Садочок» & 1 & 1 & 1 \\
\hline Готельно-ресторанний комплекс «Фортеця» & 1 & 1 & 1 \\
\hline Готельно-ресторанний комплекс «Застава» & 1 & 1 & 1 \\
\hline Комплекс відпочинку «Гонтів Яр» & 1 & 1 & 1 \\
\hline Готельно-ресторанний комплекс «Колиба» & 1 & 1 & 1 \\
\hline Готельно-ресторанний комплекс «Гуляй поле» & - & 1 & 1 \\
\hline Готельно-ресторанний комплекс «Будинок творчості вчених» & 1 & 1 & 1 \\
\hline Спортивно-розважальний комплекс «Amarant» & 1 & 1 & 1 \\
\hline Готельно-ресторанний комплекс «Sherwood» & - & 1 & 1 \\
\hline Готельно-ресторанний комплекс «Шинок на околиці» & 1 & - & 1 \\
\hline Всього & 10 & 11 & 12 \\
\hline
\end{tabular}

Джерело: сформовано за даними Сайта міста Умань (Sait mista Uman, 2018), Трипадвизор Умань (Trypadvyzor Uman, 2018), Туристический гипермаркет (Turystycheskyi hypermarket, 2018), Украина Центральная. Умань (Ukrayna Tsentralnaia. Uman, 2018), Умань туристична (Uman turystychna, 2018).

Хочеться відмітити те, що рівень індустрії гостинності Уманщині повинен стати одним із ключових факторів розвитку туризму в даному регіоні. Тому що за даними, що надав відділ туризму Уманської міської ради у 2017 році кількість туристів в Умані збільшилася в середньому на 35\%, а надходження до міського бюджету від сплати туристичного збору зросли на 27\% (Umanska miska rada, 2018). Тобто нашим містом цікавляться туристи, і це зможе надалі допомогти розвинути інфраструктуру міста та його соціально-економічний розвиток.

Отже, розвиток готельного господарства Уманщини хоч і повільними темпами, але розвивається.
Основними проблемами його розвитку є:

- невідповідність цінової політики якості наданих послуг;

- складність ведення бізнесу, що зумовлено бюрократичністю організаційного процесу функціонування підприємств сфери індустрії гостинності;

- велике податкове навантаження;

- високий рівень ризикованості інвестиційних вкладень, через нестабільну соціально-економічну та політичну ситуацію в Україні;

- конкуренція на регіональному ринку готельних послуг;

- низький рівень підготовки фахівців у галузі. 
Для готельної індустрії особливо важливо, щоб діяльність готелю була сконцентрована на певному цільовому сегменті споживачів. Сегментація дозволяє готелю розробляти і пропонувати туристам готельні послуги, призначені для конкретних споживчих сегментів та враховувати практично всі запити даного споживчого сегменту, проводити адресну рекламу, зміцнювати репутацію готелю.

Для того, щоб побачити як впливають на конкурентоспроможність готельного господарства галузеві фактори перейдемо до їх аналізу на прикладі готелю «Умань», який знаходиться в центрі міста та має давнє історичне минуле.

Основним та найбільш впливовим фактором, що впливає на конкурентоспроможність готельного господарства $є$ споживачі. Тому, що якісне обслуговування в готельному господарстві передбачає його функціонування, яке залежить від принципів та стратегії, що направлені на формування лояльних клієнтів. I для цього керівникам готельних підприємств необхідно постійно проводити аналіз готельного ри- нку, аналіз споживчих очікувань, можливості готельних підприємств по створенню і реалізації готельних послуг, які повинні відповідати споживчим потребам; здійснювати стратегічне і оперативне планування своєї діяльності з метою забезпечення прибутку.

Кожен із потенційних клієнтів готелю має свої специфічні вимоги до рівня, якості i набору запропонованих послуг, причому ні один готель не в змозі передбачити і задовольнити усі побажання споживача. Тому, при формуванні стратегії обслуговування споживачів готельних послуг необхідно зосередитися на якомусь одному або декількох споживчих сегментах і відповідно на формування основних та додаткових послуг.

У кожного готельного господарства свій контингент споживачів. Для того щоб визначити контингент клієнтів готелю «Умань» у ході дослідження було проведено анкетування 50 гостей, що допомогло в подальшому зорієнтуватися в попиті і перевагах клієнтів. Анкетування дозволило визначити вікову структуру туристів, що зупиняються в даному готелі (рис. 1).

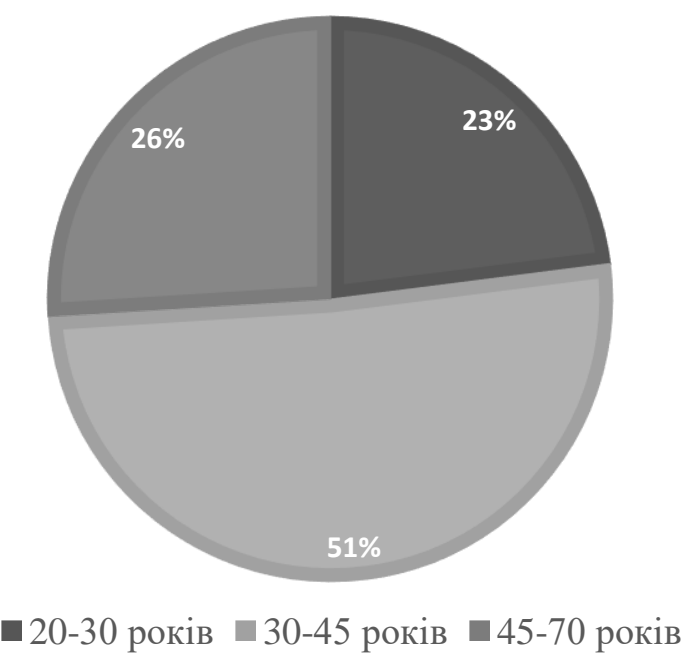

Рис. 1. Структура клієнтів готелю «Умань» (за віком) у 2018 році

Найвища питома вага серед споживачів готельних послуг готелю «Умань» складають туристи в середньому у віці від 30 до 45 років - $51 \%$ від усього числа анкетованих. Цей висновок збігається з тенденцією українського в'їзного туризму, в якому також переважає група осіб до 45 років.

Далі проаналізуємо структуру клієнтів за місцем постійного проживання рис. 2. 


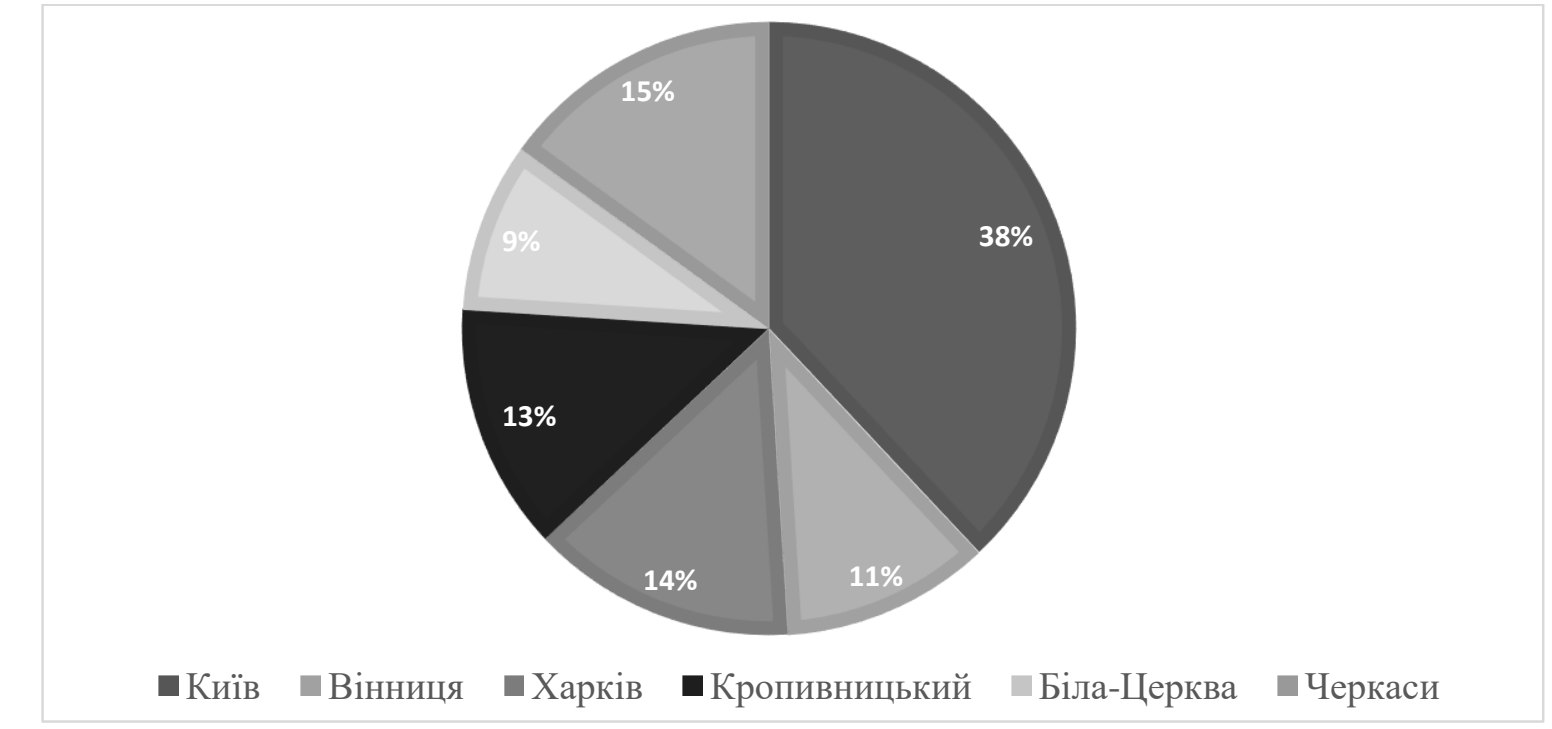

\section{Рис. 2. Структура розподілу гостей готелю «Умань» по місцю постійного} проживання за 2018 p.

У готелі переважають туристи 3 м. Київ та Київської області (38\%), 3 м. Черкас та Черкаської області (15\%). Відповідно, можна зробити висновок, що підприємству, в першу чергу, необхідно орієнтуватися на туристів з Київщини та Черкащини.

I, нарешті, для того щоб з'ясувати, на яких клієнтів слід орієнтуватися, і яку рекламну політику слід провести для залучення найбільшого числа потенційних клієнтів для готелю «Умань», було проведено анкетування серед туристів. На вулицях Умані ми задавали людям питання: «Чи чули ви про готель «Умань?». Аналіз відповідей показав, що з сотні опитаних лише $15 \%$ зупиняються в готелі «Умань», 19\% чули про готелі, 28\% іноді зупинялися i, на жаль, цілих 38\% ніколи не чули про даний готель (рис. 3).

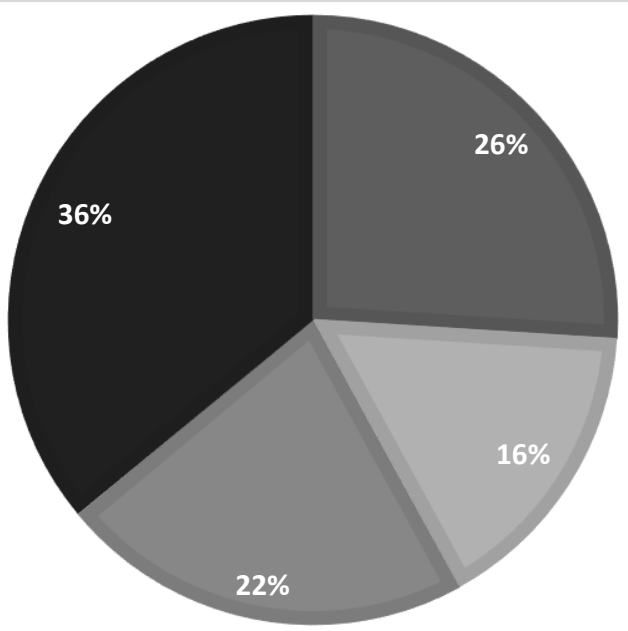

- Чули $\square$ Іноді проживали $\boldsymbol{\square}$ Завжди залишаються в цьому готелі $\boldsymbol{\square}$ Ніколи не чули

\section{Рuc. 3. Структура відповідей туристів на питання: «Чи чули ви про} готель «Умань»?»

Можна зробити висновок, що готель «Умань» має потребу у рекламі. I так як в основному більшість туристів (рис. 3) не чули про існування готелю, особливу увагу слід приділити рекламі друкованої продукціï. На даний час у готелі «Умань» переважає частка гостей, які проживають 2-3 дні (в більшості випадків це туристи) (рис. 4). 


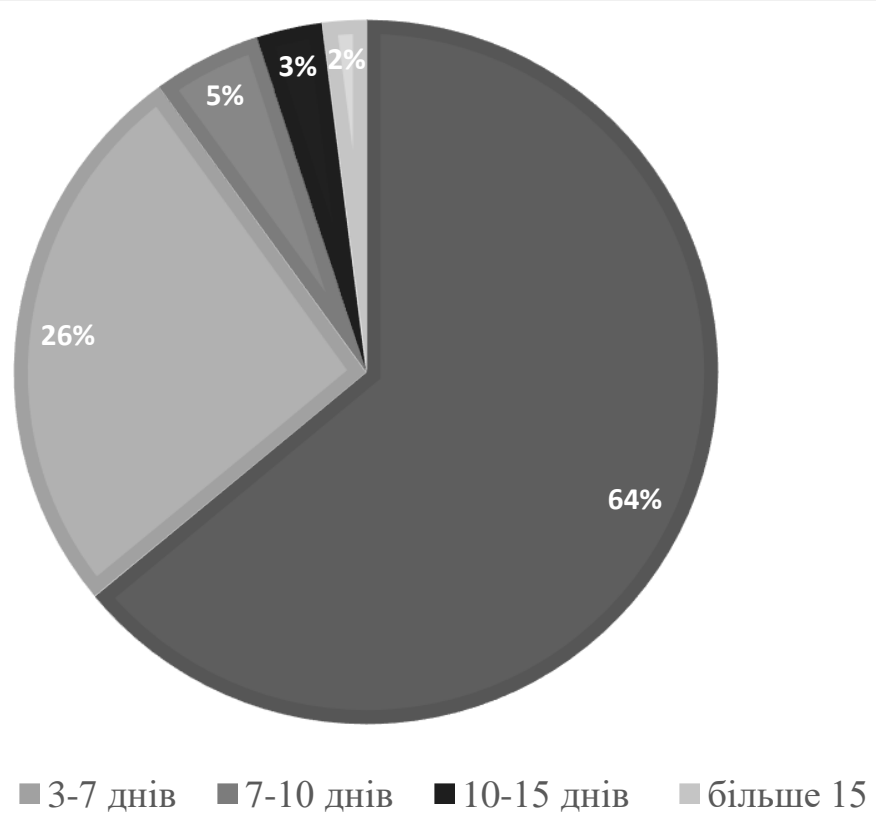

\section{Рис. 4. Структура гостей за тривалістю проживання (днів) в готелі}

Впливовим фактором на розвиток готельного господарства $\epsilon$ конкуренти. Аналіз конкурентів повинен починатися зі збору інформації з готелів, які знаходяться в територіальній близькості та мають аналогічний перелік послуг.

Даний аналіз повинен проводитися детально і моніторити усю діяльність готелів - конкурентів, а саме:

- систематизацію та аналіз реальних і потенційних можливих послуг, пропонованих конкурентами;

- визначення переліку безпосередніх конкурентів на готельному ринку даного регіону і їх потенційних можливостей;

- виявити та проаналізувати усю інформацію про виробничий, господарський, маркетинговий, фінансовий та інші види діяльності конкурентів.

Представлений перелік робіт не $є$ постійним, він може змінюватися в залежності від конкретної ситуації, специфіки готелю та його можливостей.

На жаль, в практичному житті виявити всіх конкурентів окремо взятого готелю досить складно, тому доцільно виділити саме ті готелі, які подібні за основними аспектами виробничо-господарської діяльності (табл. 3).
Аналізуючи дані табл. 3 бачимо, що конкурента позиція готелю «Умань» займає високе місце в рейтингу, і забезпечується завдяки факторам: репутація готелю, автоматизація процесом управління, якістю послуг та контролем за нею, середньорічним завантаженням (83\%), середньорічною реалізацією номерного фонду (60\%). Але адміністрації готелю необхідно звернути увагу на проблемні місця, зокрема: кваліфікацію менеджерів, плинність кадрів, маркетингову політику.

Одним із факторів впливу на конкурентоспроможність готельного господарства $є$ маркетингові посередники, які займаються маркетинговими дослідженнями готельного ринку, рекламою готельних послуг, просуванням готельних послуг на ринок та їх реалізацією. Найбільш ефективними на даний час $є$ такі канали реалізації готельних послуг: корпоративні агентства, які реалізують номерний фонд готелю і отримують за це комісію; call-центри компаній, що займаються обробкою заявок від туристів і передають їх до відділів бронювання готелів; глобальні системи резервування (наприклад, Amadeus, Galileo) готельні брокери (наприклад, Booking.com). 
Таблиця 3. Порівняльна характеристика готелю «Умань» та його конкурентів

\begin{tabular}{|c|c|c|c|c|}
\hline \multirow[b]{2}{*}{ № } & \multirow[b]{2}{*}{ Показники } & \multirow[b]{2}{*}{$\begin{array}{l}\text { Готель } \\
\text { «Умань» }\end{array}$} & \multicolumn{2}{|c|}{ Конкуренти } \\
\hline & & & ГРК «Фортеця» & $\begin{array}{c}\text { Готель } \\
\text { «Софіївський» }\end{array}$ \\
\hline 1. & \multicolumn{4}{|c|}{ Фактори, що характеризують рівень розвитку готелю } \\
\hline 1.1. & Репутація (імідж) готелю & Відомий & Відомий & Відомий \\
\hline 1.2 . & Кваліфікація менеджерів вищої ланки & Середній & Середній & Середній \\
\hline 1.3. & Автоматизація управління готелем & Висока & Висока & Висока \\
\hline 1.4 . & Плинність кадрів & Висока & Висока & Висока \\
\hline 2. & \multicolumn{4}{|c|}{ Фактори, що характеризують виробництво і надання послуг } \\
\hline 2.1. & Середня ціна номеру, грн & $303-1010$ & $450-1800$ & $150-500$ \\
\hline 2.2 & Асортимент послуг & Середній & Середній & Низький \\
\hline 2.3. & Якість послуг & Добра & Добра & Задовільна \\
\hline 2.4 . & Контроль якості наданих послуг & Постійний & Постійний & Постійний \\
\hline 3. & \multicolumn{4}{|c|}{ Фактори, що характеризують завантаження готелю } \\
\hline 3.1. & Середньорічне завантаження, \% & 83 & 80 & 30 \\
\hline 3.2 . & Частка номерного фонду, зданого в оренду, \% & - & - & - \\
\hline 3.3. & $\begin{array}{l}\text { Середньорічна реалізація номерного фонду по } \\
\text { попереднім заявкам (бронювання), \% }\end{array}$ & 60 & 58 & 36 \\
\hline 4. & \multicolumn{4}{|c|}{ Фактори, що характеризують структуру гостей } \\
\hline 4.1. & $\begin{array}{l}\text { Частка ділових туристів в загальному серед } \\
\text { гостей,\% }\end{array}$ & 60 & 62 & 34 \\
\hline 4.2 . & $\begin{array}{l}\text { Частка корпоративних клієнтів у сегменті } \\
\text { ділових гостей,\% }\end{array}$ & 57 & 55 & 45 \\
\hline 5. & \multicolumn{4}{|c|}{ Фактори, що характеризують маркетингову політику } \\
\hline 5.1. & Маркетингова стратегія & $\begin{array}{c}\text { Запро- } \\
\text { ваджені } \\
\text { окремі еле- } \\
\text { менти } \\
\end{array}$ & $\begin{array}{c}\text { Запроваджені } \\
\text { окремі елементи }\end{array}$ & $\begin{array}{c}\text { Запроваджені } \\
\text { окремі елементи }\end{array}$ \\
\hline 5.2 . & Реклама & $\begin{array}{l}\text { Недо- } \\
\text { статня }\end{array}$ & Недостатня & Недостатня \\
\hline
\end{tabular}

Джерело: розраховано авторами.

Аналізуючи дані табл. 3 бачимо, що конкурента позиція готелю «Умань» займає високе місце в рейтингу, і забезпечується завдяки факторам: репутація готелю, автоматизація процесом управління, якістю послуг та контролем за нею, середньорічним завантаженням (83\%), середньорічною реалізацією номерного фонду (60\%). Але адміністрації готелю необхідно звернути увагу на проблемні місця, зокрема: кваліфікацію менеджерів, плинність кадрів, маркетингову політику.

Одним із факторів впливу на конкурентоспроможність готельного господарства $\epsilon$ маркетингові посередники, які займаються маркетинговими дослідженнями готельного ринку, рекламою готельних послуг, просуванням готельних послуг на ринок та їх реалізацією. Найбільш ефективними на даний час є такі канали реалізації готельних послуг: корпоративні агентства, які реалізують номерний фонд готелю і отримують за це комісію; call-центри компаній, що займаються обробкою заявок від туристів і передають їх до відділів бронювання готелів; глобальні системи резервування (наприклад, Amadeus, Galileo) готельні брокери (наприклад, Booking.com).

Готель «Умань» по структурі розподілу номерного фонду по каналах збуту реалізує найбільше своїх послуг через прямий продаж (рис. 5). 


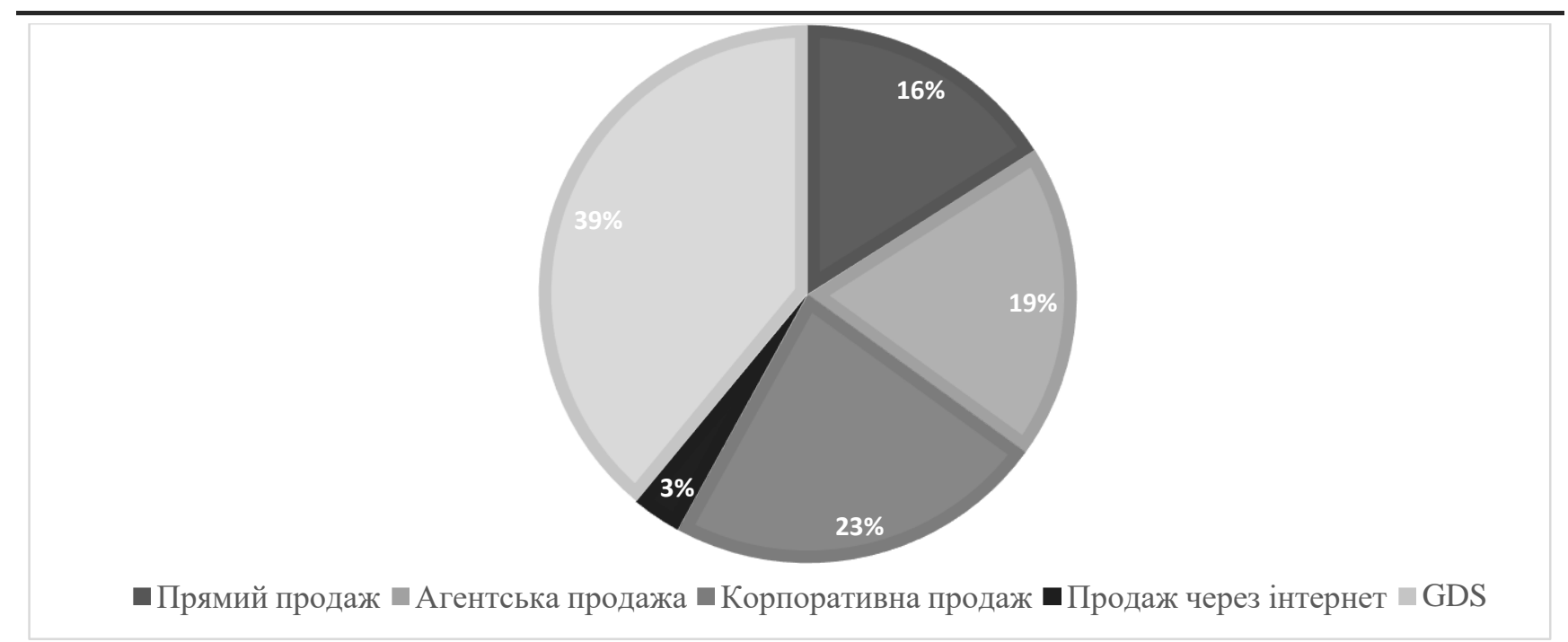

\section{Рис. 5. Структура розподілу замовлень номерного фонду готелю «Умань» за каналами збуту}

До вибору маркетингових посередників власники готелю повинні підходити дуже відповідально, тому що від їх роботи залежить імідж готелю та ефективність продажів їх послуг. Регулярно готель повинен оцінювати обсяг реалізованих готельних послуг у пік та спад продажів, досліджувати знижки та системи заохочення та виплачувати посередникові винагороду.

Засоби масової інформації (друковані видання, Інтернет, телебачення, радіо) мають на даний час дуже великий вплив на формування громадської думки про послуги і на зміну попиту.

Тому готелям необхідно активно співпрацювати зі 3МІ. Однак, при роботі із засобами масової інформації необхідно проводити ретельний аналіз тиражу, спрямованості даних 3МI, їх цільової аудиторії.

Ще одним фактором впливу $\epsilon$ контактна аудиторія. Ефективна робота готелю на ринку повинна дотримуватися регіональних та місцевих законів, умов ведення бізнесу, традицій та цінностей.

I останнім фактором впливу на розвиток конкурентоспроможності готельного господарство є союзи та асоціації. Саме вони лобіюють нормативно-правові акти та стандарти обслуговування на державному рівні, а також представляють готелі на міжнародному ринку. До основних цілей функціонування готельних асоціацій слід віднести: формування стійкого попиту на готельні послуги України; участь у формуванні і розробці нормативно-правових положень у сфері індустрії гостинності; підвищення якості прийому та обслуговування туристів у тому числі і іноземних; формування нових готельних послуг; застосування на практиці міжнародних стандартів та створення єдиного інформаційного простору для збору статистичних даних про розвиток готельного господарства; консультаційна допомога засобам розміщування.

Отже, ринок готельних послуг Уманщини $є$ помірно концентрованим, а інтенсивність конкуренції невисока.

Формування конкурентних переваг $\epsilon$ трудомістким процесом і повинен потребувати від готелів постійної роботи по удосконаленню своєї діяльності, так як більшість ресурсів які створюють конкурентні переваги готелю легко можуть бути скопійовані конкурентами. Тому, терміни впровадження інноваційних технологій повинні бути менші за терміни їх освоєння.

Конкурентна перевага підприємства готельного господарства може бути забезпечена як відмінними особливостями продукту, що виробляється, так і сукупністю ресурсів, умінь, навичок, що характеризують внутрішній потенціал готелю. Тобто конкурентна перевага готельного підприємства - це ті властивості готельних 
послуг, які створюють для готелю певну перевагу над їі прямими конкурентами. Ці характеристики можуть бути неоднаковими та відноситись як до базових послуг готельного підприємства (розміщення, харчування), так і до додаткових послуг, технологій обслуговування клієнтів, до форм ринкового просування послуг, специфічних для конкретного готелю (Malska and Pandiak, 2009).

Готелю «Умань» необхідно мати свої джерела конкурентних переваг які повинні бути засновані на високій репутації, лояльному та професійному персоналі, ефективному маркетингу та використанні ефективних систем управління.

Формування конкурентоспроможного готельного господарства можливе лише за умови формування конкурентоспроможної ринкової стратегії окремими готельними підприємствами регіону і країни та підвищенню всього туристського продукту (Khmurova, 2014).

Для того щоб створити стабільні конкурентні переваги або повною мірою використовувати вже наявні, готельним підприємствам необхідно застосовувати різні конкурентні стратегї (Zavidna, 2018).

Але слід пам'ятати, що при формуванні певних рекомендацій (пропозицій) щодо управління конкурентоспроможності готельних послуг для всіх підприємств бути стандартними не можуть. Вони повинні бути сформовані для кожного підприємства свої, які оптимально будуть працювати 3 урахуванням усіх специфічних характеристик та особливостей даного підприємства.

Уже стало закономірно, що готельна послуга повинна бути конкурентоспроможна, інакше на неї не буде попиту або він буде дуже низький. Але не слід забувати, що обов'язковою умовою конкурентоспроможності послуги є відповідність ціни та якості обслуговування.

Резерви зростання конкурентоспроможності готельних послуг, необхідно шукати у внутрішніх чинниках самого підприємства: виробничо-господарська діяльність готелю; особливості, та специфіка готельних послуг; маркетингова діяльність готелю (рис. 6).

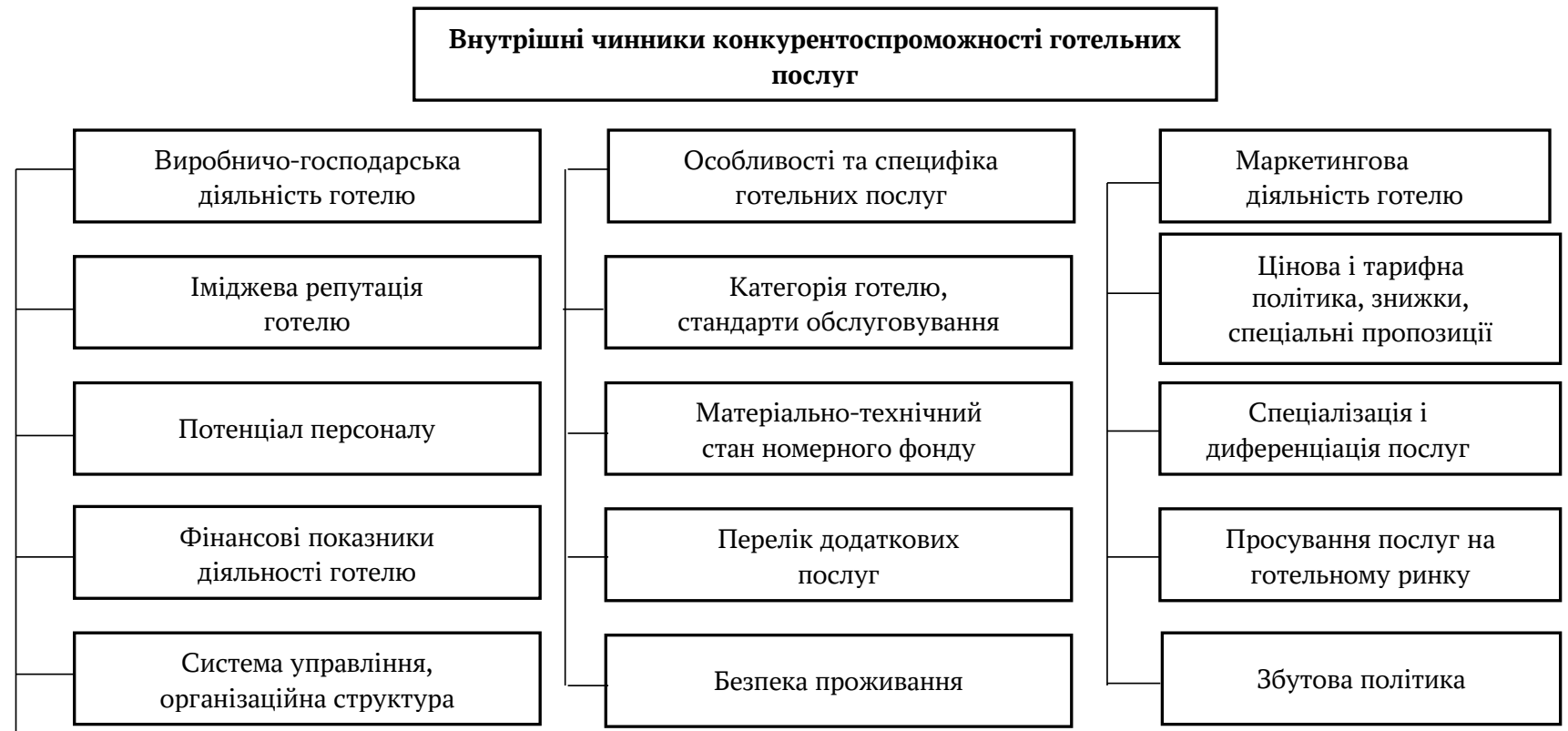

Місцезнаходження готелю

Pис. 6. Групи внутрішніх чинників, які визначають конкурентоспроможність готелю

Джерело: авторська розробка. 
Шляхи підвищення конкурентоспроможності засобів розміщення по першій групі чинників формуються: на основі розвитку організаційної культури, мотивування співробітників, фірмового стилю, просуванні іміджу готелю на готельному ринку; вдосконалення використання кадрового потенціалу готелю шляхом розробки переліку вимог до співробітників на кожному робочому місці, визначення можливостей працівників, вивчення ступеня використання кадрів готелю; ефективне використання наявних фінансових коштів готелю 3 урахуванням перспективних напрямків діяльності; оптимізація організаційної структури управління готелів, чітке розмежування функцій управління та відповідальності між службами готелю; підвищення кваліфікації персоналу готелю на всіх рівнях управління.

Власникам потрібно оптимізувати віддачу від вкладень капіталу не тільки у матеріальні та фінансові ресурси, а й у людські. Тобто створити комфортні умови для праці, вміти проаналізувати і запроваджувати актуальні методи роботи, мотивувати та підтримувати ініціативу своїх працівників, навчати та розвивати їхні вміння й навички. Адже ми знаємо, що на сучасному етапі розвитку вирішальну роль у забезпеченні сталих темпів економічного зростання відіграє людський капітал і надзвичайно важливо, щоб підприємці, держава сприяла його розвитку та формуванню. Він $\epsilon$ основою економічного зростання в будьякій галузі, а не природні ресурси. Цей висновок підтверджують Корея, Сінгапур, Тайвань, які, не маючи власної ресурсної бази, але володіючи високоякісним людським капіталом, досягли значних успіхів у глобальній конкуренції (Povorozniuk, 2017).

Шляхи підвищення конкурентоспроможності засобів розміщення по другій групі чинників: використання гнучкої системи цін з метою максимізації завантаженості готелю на основі аналізу ціноутворення; забезпечення відповідності якості наданих готельних послуг рівню готелю, його категорії; регулярне оновлення номерного фонду готелю, проведення поточних і капітальних ремонтів, оснащення номерів відповідно до вимог категорії готелю; впровадження інноваційних рішень, які дозволять забезпечити гостям готелю більш сприятливі умови проживання; реалізація в готелі сучасних логістичних систем управління транспортом, складуванням та постачанням; дотримання стандартів обслуговування в готелях, а також заходів санітарної та протипожежної безпеки; забезпечення безпеки туристів в готелі та їх майна; розширення переліку додаткових послуг, що надаються в готелі; підвищення культури обслуговування; повсюдне впровадження міжнародних стандартів обслуговування; впровадження сучасних автоматизованих систем управління.

Шляхи підвищення конкурентоспроможності засобів розміщення на основі використання маркетингу в готелях: вдосконалення ціноутворення на основі аналізу попиту і пропозиції, розробки систем знижок, диференціації цін та інше; вдосконалення політики просування готельних послуг на ринок, розвиток різноманітних форм співробітництва 3 організаціями турбізнесу, 3MI, конгрес-центрами, великими корпораціями, міжнародними організаціями; подальша диференціація готельних послуг, асортименту пропозицій для клієнтів готелю відповідно до вимог споживачів; вдосконалення збутової політики на основі постійного контролю ефективності збутових каналів.

Щоб сформувати цільові орієнтири стратегічного розвитку готельного господарства необхідно розробити систему збалансованих показників, яка дасть можливість адаптуватися до конкретних умов 3овнішнього та внутрішнього середовища організації, підвищить рівень іiі конкурентоспроможності та збільшить задоволеність споживачів. У кінцевому результаті це призведе до підвищення ефективності роботи внутрішніх процесів на виробництві та підвищить прибуток підприємства.

Аналізуючи заклади розміщування, ми дійшли висновків, що основними збалансованими показниками підвищення 
рівня конкурентоспроможності готельних послуг регіону є: відсоток збільшення прибутку; середня ціна номера; відсоток збільшення числа споживачів в несезонний період; кількість постійно зайнятих номерів; кількість нових послуг; кількість позитивних відгуків в гостьовій книзі; кількість нових шляхів залучення клієнтів; час на обслуговування одного клієнта; кількість скарг на обслуговування; кількість позитивних відгуків на сайті; витрати на навчання співробітників.

Також необхідно, щоб була сформована відповідна стратегічна програма яка мала б конкурентні шляхи реалізації яка повинна формуватися на: розробці програм заохочення клієнтів; розробці системи гнучких знижок під час несезонних періодів; ефективній маркетинговій діяльності; автоматизації системи управління усіма ланками виробничої структури; створенні інформаційної системи оцінки думок споживачів; програмах навчання персоналу та визначення рівня його задоволеності.

Необхідно підкреслити, що заходи тільки по одному з виділених вище напрямків не підвищить конкурентоспроможність готелю. Завжди, при розробці стратегічних i оперативних рішень необхідно враховувати всі фактори, що впливають на конкурентну позицію готелю. Тобто, заходи по підвищенню конкурентоспроможності готелю повинні носити комплексний характер.

3 метою подальшого підвищення конкурентоспроможності послуг менеджменту готелів необхідно постійно контролювати якість надання готельних послуг, максимально враховувати потреби клієнтів та звести до мінімуму розбіжності між очікуваним та фактичним рівнем якості готельних послуг.

\section{6. Висновки.}

Процес формування конкурентоспроможності готельних послуг є трудомістким процесом та вимагає від готелів постійної роботи по удосконаленню свої діяльності тому, що більшість ресурсів які створюють конкурентні переваги є легко доступні для конкурентів відповідної сфери діяльності.

У роботі виявлено, що однією із проблем розвитку готельного бізнесу в регіоні $\epsilon$ дефіцит бюджетного розміщування; складність економічної ситуації, пов'язаної із значними витратами на утримання та експлуатацію номерного фонду; підвищення тарифів на комунальні послуги; податковий тиск; недостатнє використання потенціалу готельних підприємств регіону; низька конкурентоспроможність матеріально-технічної бази готелів; стан міської інфраструктури; проблеми нормативноправового характеру; невідповідність цін рівню якості надання готельних послуг; рекламно-інформаційне забезпечення.

Запропоновано резерви росту конкурентоспроможності готельних послуг регіону, які необхідно шукати у внутрішніх факторах розвитку підприємства що характеризують його виробничо-господарську діяльність; особливості та специфіку готельних послуг; якість обслуговування споживачів готелю; маркетингову діяльність.

Доведено, що конкурентні переваги готелю формуються на основі ефективного використання підприємством усіх його наявних ресурсів, які потребують постійної роботи по удосконалення своєї діяльності.

У подальших дослідженнях вимагає кількісного обгрунтовування система показників, за допомогою яких можна виміряти конкурентоспроможність готельної послуги регіону.

\section{References}

Batchenko, L. V. and Starychenko, T. V. (2018), "Conceptual approach of competitiveness of hotel business in Ukraine”, Efektyvna ekonomika, vol. 9, available at: http://www.economy.nayka.com.ua/pdf/9 2018/9.pdf (Accessed 20 August 2018).

Fraj, E., Matute, I. and Melero, I. (2015), "Environmental strategies and organizational competitiveness in the hotel industry: the role of learning and innovation as determinants of environmental success", Journal of Tourism Management, vol. 46, pp. 30-42, doi: https://doi.org/10.1016/j.tourman.2014.05.009. 
Halasiuk, S. (2014), "Estimation of competitiveness of the hotel industry enterprises in Odessa region", Ekonomika. Upravlinnia. Innovatsii, vol. 2, available at: http://nbuv.gov.ua/UJRN/eui_2014_2_17 (Accessed 20 August 2018).

Khmurova, V. (2014), "Formation of the mechanism of competitiveness at hotel enterprises", Visnyk KIBIT, vol. 3(25), pp. 112-116.

Kotler, F. (2006), Marketing menedzhment. Ekspress-kurs [Marketing management. Express course], Piter, St. Petersburg, Russia.

Li L., Peng, M., Jiang, N. and Law, R., (2017), “An empirical study on the influence of economy hotel website quality on online booking intentions", Journal of International Journal of Hospitality Management, vol. 636 pp. 1-10, doi: https://doi.org/10.1016/j.ijhm.2017.01.001.

Malska, M. P., and Pandiak, I. H. (2009), Hotelnyi biznes: teoriia ta praktyka [Hotel business: theory and practice], Tsentr navch. lit., Kyiv, Ukraine.

Mohammed, I., Guillet, B. and Law, R. (2015), “The contributions of economics to hospitality literature: A content analysis of hospitality and tourism journals", Journal of International Journal of Hospitality Management, vol. 44, pp. 99-110, doi: https://doi.org/10.1016/j.ijhm.2014.10.010.

Molina-Azorín, J., Tarí, J., Pereira-Moliner, J., López-Gamero, M. and Pertusa-Ortega, E. (2015), “The effects of quality and environmental management on competitive advantage: A mixed methods study in the hotel industry", Journal of Tourism Management, vol.50, pp.41-54, doi: https://doi.org/10.1016/j.tourman.2015.01.008.

Okhota, V. (2017), "Ways to improve the competitiveness of enterprises hospitality industry", Investytsiyi: praktyka ta dosvid, vol. 5, pp. 46-49.

Podlepina, P. (2016), "The tendencies of development of Ukrainian hotel economy in conditions of turbulence", Visnyk Kharkivskoho natsionalnoho universytetu imeni V. N. Karazina, vol. 5, pp.154-159.

Poltavska, O. (2016), "Ensuring efficiency of enterprises hotel industry”, Ekonomika ta derzhava, no. 11, pp. 2529.

Povorozniuk, I. M. (2017), “Effective personnel motivation system for hospitality industry as a precondition of success in the services market”, Ekonomichnyi analiz,_vol. 27, no. 3, pp. 204-212.

Shykina, O. V. (2016), "Modern state of the hotel busines of Odessa region”, Hlobalni ta natsionalni problemy ekonomiky, vol. 13, pp. 413-420, available at: http://global-national.in.ua/archive/13-2016/83.pdf (Accessed 20 August 2018).

Spravochnyk Umani (2018), ), available at: http://uman.spravker.ru/ (Accessed 20 August 2018).

The web-site of Ukraina Tsentralna. Uman (2018), available at: http://discover-ukraine.info (Accessed 20 August 2018).

The web-site of Uman city (2018), available at: https:/04744.info/ (Accessed 20 August 2018).

The web-site of Uman turystychna (2018), available at: http://umantravel.com.ua (Accessed 20 August 2018).

The web-site of Umanska miska rada, (2018), available at: http://uman-rada.gov.ua/index.php/dokumenty/rishennia-miskoi-rady (Accessed 20 August 2018).

Tkachenko, A. and Leli, Yu. (2016), “The problems and perspectives of problems and perspectives of hotel business in today's conditions”, Prychornomorski ekonomichni studii, vol. 12, part 1, pp.185-188.

Trypadvyzor Uman (2018), available at: https://www.tripadvisor.ru/Tourism-g673500-Uman Cherkasy_OblastVacations.html (Accessed 20 August 2018).

Turystycheskyi hypermarket (2018), available at: http://travelnetplanet.com/ukraine/cherkasskaya (Accessed 20 August 2018).

Zavidna, L. (2018), “A strategy for ensuring enterprise competitiveness in the sphere of hotel services", The problems of economy, vol. 1, pp. 187-193.

Zervas, G., Proserpio, D. and Byers, J. (2017), "The rise of the sharing economy: Estimating the impact of Airbnb on the hotel industry", Journal of Marketing Research, vol. 54, no. 5, pp. 687-705, doi: https://doi.org/10.1509/jmr.15.0204.

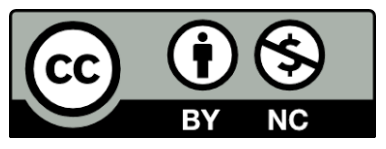

Цей твір ліцензовано на умовах Ліцензії Creative Commons «/з Зазначенням Авторства - Некомериійна 4.0 Міжнародна» (CC BY-NC 4.0). This is an open access journal and all published articles are licensed under a Creative Commons "Attribution-NonCommercial 4.0 International" (CC BY-NC 4.0). 